\title{
EVALUATIVE CONCEPTS IN EUROPEAN PRIVATE LAW
}

\author{
Valery G. Golubtsov \\ Perm State National Research University, Perm, Russian Federation
}

\begin{abstract}
Introduction: the author refers to the generalizing concepts contained in the Model rules of European Private Law (DCFR). According to the Russian tradition, emerged in the Soviet legal science, such concepts are referred to as evaluative ones. The positive and negative results of their use by the legislator in the text of normative acts are sufficiently investigated in the doctrine. The main part of the research in this direction concerns the definition of these concepts and the legal uncertainty reported to the law by such concepts. Purpose: based on studying the experience of using evaluative concepts in the administration of justice in the European countries on the basis of supranational norms, to address the problems of applying these evaluative concepts in the post-reform period. Methods: the methodological framework for the research was the general scientific (dialectical) method of cognition. The specific scientific methods of cognition such as comparative law, formal legal, logical, and systematic approaches were also used. Results: european private law adopted a different approach to the perception of evaluative concepts, which has gained today the status of supranational law for Europe. In European private law, the generalizing concepts have a certain hierarchy at the top of which there is such a thing as "good faith and honest business practice", which acts as a general clause that permeates all the institutions and their concepts. Conclusions: thus, as higher order constructs, the generalizing concepts are of interest to science, practice and the legislator from the standpoint of the objectives of law, the general principles of law and values that are above the law.

Key words: model rules, supranational law, standards, normative generalizations, integrity, honest business practice.

Citation. Golubtsov V.G. Evaluative Concepts in European Private Law. Legal Concept, 2019, vol. 18, no. 2 , pp. 19-29. (in Russian). DOI: https://doi.org/10.15688/lc.jvolsu.2019.2.3

УДК 343

ББК 67.404 .2

Дата поступления статьи: 26.02.2019

Дата принятия статьи: 01.04.2019
\end{abstract}

\section{ОЦЕНОЧНЫЕ ПОНЯТИЯ В ЕВРОПЕЙСКОМ ЧАСТНОМ ПРАВЕ}

\author{
Валерий Геннадьевич Голубцов \\ Пермский государственный национальный исследовательский университет, \\ г. Пермь, Российская Федерация
}

Введение: автор обращается к обобщающим понятиям, содержащимся в Модельных правилах европейского частного права (DCFR), которые по российской традиции, возникшей в советском правоведении, именуются оценочными. Положительные и отрицательные результаты их использования законодателем в тексте нормативных актов в достаточной степени изучены в доктрине. Основная часть исследований в этом направлении касается доктринального определения этих понятий и правовой неопределенности, сообщаемой праву такими понятиями. Цель: опираясь на исследования опыта применения оценочных понятий при осуществлении правосудия в Европейских странах на основе наднациональных норм, обратиться к проблемам применения оценочных понятий в пореформенный период. Методы: методологическую основу статьи ๓ составил общенаучный (диалектический), а также частнонаучные методы познания: сравнительно-правовой, формально-юридический, логический, системный подходы. Результаты: в европейском частном праве принят иной подход к воспринятию оценочных понятий, получивший сегодня статус наднационального Брава для стран Европы. В европейском частном праве обобщающие понятия имеют некую иерархию, на () вершине которой стоит такое понятие, как «добросовестность и честная деловая практика», выполняющее 
роль генеральной оговорки, пронизывающей все институты и входящие в них понятия. Выводы: обобщающие понятия как образования более высокого порядка интересуют науку, практику и законодателя с позиций целей закона, общих принципов права и надзаконных ценностей.

Ключевые слова: модельные правила, наднациональное право, стандарты, нормативные обобщения, добросовестность, честная деловая практика.

Цитирование. Голубцов В. Г. Оценочные понятия в европейском частном праве // Legal Concept = Правовая парадигма. -2019. - Т. 18, № 2. - C. 19-29. - DOI: https://doi.org/10.15688/lc.jvolsu.2019.2.3

«Пусть право каждого народа остается прежде всего его собственным, национальным правом; но да избавит его судьба от забвения о праве других народов» [23].

\section{Введение}

Европа считается родиной частного права. Ее исторически ранний и высокий уровень развития цивилистики и кодификационная активность стали определяющими в развитии законодательства, науки и образования в вопросах формирования национальной и международной практики регулирования имущественных отношений для многих стран. Начиная с 80-х гг. прошлого века эта практика стала дополняться общеевропейской или наднациональной, которой пока приписывается «шарм неизвестности и, по крайней мере, с виду, политической невинности» [25, с. 26-33].

Идея создания «единого европейского частного права», как одна из центральных идей в конце XX - начале XXI в., возникла одновременно с тенденцией усиления роли частного права в Европейском сообществе [5; 10; 18]. По мнению зарубежных ученых, ее практическая реализация «зависит от степени политического, экономического, социального и иного объединения европейских стран в одно целое» [28].

В российских политических и правовых воззрениях эти идеи получили распространение в 2008 г., получив последующее закрепление в Концепции развития гражданского законодательства Российской Федерации. На законодательном уровне был установлен ориентир на «сближение положений Гражданского кодекса РФ с правилами регулирования соответствующих отношений в праве ЕС» и «использование в гражданском законодательстве Российской Федерации новейшего положительного опыта модернизации гражданских кодексов ряда европейских стран» [12].
В основе процессов европеизации частного права лежит гармонизация права европейских государств. Сменив некогда свой стихийный и односторонний характер на целенаправленный и взаимный процесс сближения национальных законодательств европейского континента, она направила рецепцию права не по этому пути.

Источником современных представлений о путях развития европейского частного права являются документы, ориентированные на сближение, гармонизацию и координацию норм национального частного права. Эти акты, не будучи нормами национального законодательства, являют собой результат академического взаимодействия ученых разных стран. Имея доктринальный статус «интеллектуального продукта, отражающего современный уровень гражданско-правовой мысли» [8, с. 56-61], они, в частности, ориентируют страны континента на общеевропейские установления по вопросам договорного права, а страны с не до конца устоявшимся законодательством в этой сфере - направления его совершенствования и развития.

К числу таких документов можно отнести: Принципы, определения и модельные нормы европейского частного права: Проект общей справочной системы (Principles, Defi nitions and Model Rules of European Private Law: Draft Common Frame of Reference [DCFR]) 2009 г. в двух русскоязычных переводах, выполненных Б.И. Пугинским и А.Т. Амировым [20] и авторским коллективом, руководимым Н.Ю. Рассказовой [15]; Кодекс европейского договорного права (European Contract Code (ЕСC)) 2001-2007, ставший общедоступным благодаря переводу В.А. Белова [7, с. 557-561].

Различие данных актов происходит от статуса организаций, инициировавших их составление, задач этих актов, года появления и предпосылок, обусловивших их разработку соответствующими академическими сообществами. 
Объединяет же указанные документы общее тематическое начало, состоящее в том, что наиболее важной и приоритетной сферой сближения национальных законодательств они объявляют договорно-обязательственное право, весьма благодатным для целей современной наднациональной гармонизации.

Гармонизации европейского договорного права исторически предшествовала его международная унификация. Зародившись более 2000 лет назад, данное право, начиная с XIX в., наиболее явно проявило тенденцию сначала к международному, а после к наднациональному характеру, в отличие от права вещного, где в большей степени преобладает национальное. Это нашло подтверждение в нормах Модельных правил европейского частного права (далее - Модельные правила), касающихся отдельных аспектов вещного права и в отдельных нормах отсылающих к национальному законодательству (VIII.-1:102; VIII.-2:103; IX.-3:301; IX.-3:312). Нормы о договорах подобных отсылок не содержат.

Вне зависимости от того, чего больше придерживались авторы переводов - терминологического значения национально-правового контекста или идеи гармонизации правовых понятий договорного права на европейском уровне, нельзя не отметить безусловную мировоззренческую ценность состоявшегося перевода. Как указано в Предисловии к Модельным правилам частного права, во-первых, DCFR подтверждает, что российское гражданское право по-прежнему находится в «близких родственных отношениях» с частным правом европейских государств, относящихся к континентальной правовой системе. Мы можем понять «их», «они»- нас, мы можем развиваться в одном направлении, что в условиях глобализации, безусловно, является немаловажным для развития внутреннего рынка. Во-вторых, DCFR воплощает современную модель гражданского права. В-третьих, DCFR является важным шагом на пути примирения правовых систем гражданского и общего права. DCFR будет рассматриваться как текст, из которого можно черпать вдохновение для оптимального решения проблем частного права [1, с. 17-47].

Если говорить о доктринальной ценности состоявшихся русскоязычных переводов
Принципов Европейского договорного права, Модельных правил европейского частного права как части этих Принципов, а также Кодекса европейского договорного права, то нельзя не признать, что в распоряжении отечественной науки гражданского и коммерческого права появился весьма значимый научный и законодательный материал, способный стать как толчком для развития отдельных направлений российской цивилистической науки, так и для переосмысления некоторых устоявшихся теоретических постулатов.

В российской цивилистике пока не обозначился устойчивый предметный интерес к проблематике европейского гражданского права, как и к исследованию узконаправленных теоретических вопросов, но почины уже имеются [2, с. 85-94; 3, c. 71-118; 7; 13, с. 166-179].

В настоящей работе, опираясь на текст Модельных правил в русскоязычном переводе под редакцией Н.Ю. Рассказовой, мы обратимся к таким обобщающим понятиям европейского договорного права, которые в российском праве именуются оценочными и постараемся выявить особенности восприятия этих категорий.

\section{Учение об оценочных понятиях в российском гражданском праве}

Алгоритм исследования оценочных понятий, их влияние на качество нормативной материи и практику правоприменения с позиций правовой неопределенности и границ судейского усмотрения, сформировался в советском правоведении. Изначально как понятия, обладающие содержательной подвижностью, они получили название «каучуковых параграфов». Вслед за И.А. Покровским, считавшим использование таких параграфов уклонением от решения проблемы доступа идей естественного права в положительное законодательство [17, с. 103], такие понятия были привнесены в советское правоведение И. Разумовским (1926) и А.Г. Зейцем (1928), однако уже под другим идейным началом.

Не без влияния философской науки, использовавшей категорию «оценка» (мерило) и проникшей в XX в. практически во все общественные науки, термин «оценочный» закрепился в правоведении и «каучуковые» по- 
нятия, имея некую общность наименования с зарубежными аналогами, получили название оценочных. Произошло это во время полного размежевания с буржуазным правом на фоне теоретического переосмысления и «инструментального», догматического механизма советского права. Одним из последствий такого переосмысления явился взгляд на вычленение в праве нормативных понятий с оценочным содержанием как понятий, которые «придают нормам права эластичный характер» [6, с. 3-18].

Оценочные понятия, как и те, которые имеют «относительно-неопределенное содержание» и «открытую логическую структуру», продолжают осваиваться в российском правоведении и сегодня. Но методика их доктринального освоения по-прежнему находится под влиянием советского права.

При всем множестве научных взглядов и мнений теоретическая полемика все больше строится на замкнутой системе понятий и взглядов на проблему. Основные дискуссии продолжают разворачиваться вокруг доктринального осмысления самой категории «оценочные понятия», сообщая тем самым этому предметному учению излишнюю склонность к теоретизации при недостаточности внимания к практическим потребностям права. Из этого продолжает исходить российская правовая доктрина, признающая в существовании оценочных понятий одновременно положительный момент, придающий праву характер гибкого, подвижного, эластичного феномена, снижающего жесткость правового регулирования, и отрицательный, следствием которого является эффект неопределенности в праве, субъективизм и чреватость судебного произвола.

К числу эволюционных подвижек в структуре учения об оценочных понятиях можно считать факт определения оценочного понятия специалистами по законотворческой технике. Оно раскрыто как понятие, в котором свойства, признаки, детали правовых явлений подробно не разъясняются законодателем, а оцениваются и конкретизируются субъектами исходя из эталонов правосознания, практики, нравственности, обычаев и т. д. [8, с. 147-148]. Данное определение больше является исключением, нежели общим системным подходом в исследовании этих обоб- щений для целей правотворчества. Но оно появилось, неся на себе признаки объективности, масштабной значимости для целей правотворчества и правового регулирования, имея признаки некоторой сопоставимости с зарубежными представлениями о сущности таких понятий.

Еще одним критерием эволюционности данного учения можно считать выводы о неоднозначном их значении в отраслях права публичного и права частного с заключением о том, что содержание и признаки оценочных понятий зависят от их отраслевой принадлежности [24, с. 12]. В качестве отличительных черт оценочных понятий в гражданском праве были названы: диспозитивность и возможность вариативности содержания оценочного понятия по соглашению сторон независимо от существующей судебной практики либо обычая оборота, делового обыкновения; выражение и закрепление не только в нормах гражданского законодательства, но и в гражданско-правовых договорах и сделках; оценочные понятия гражданского права, исходя из самого содержания цивилистики, наименее поддаются унификации, что обусловлено в первую очередь принципом равенства участников гражданских правоотношений [24, с. 12].

Весьма символичным и во многом приближающимся к зарубежной практике является подход, демонстрирующий, что сама категория «оценочные понятия» вольно или невольно оказалась точкой пересечения нескольких терминов правового значения. В его рамках, например, актуальная категория добросовестности рассматривается в нескольких значениях: принципа, презумпции, оценочного понятия [22, с. $10-11]$. В этом усматриваются методологические предпосылки для нового подхода к категории «добросовестность», изначально исследуемой в рамках теории «каучуковых» понятий, позднее проблемой презумпций. Именно такое положение А.Л. Маковский признал «странным подходом» в тех условиях, когда «принцип добросовестности так или иначе, в праве или в законе (чаще всего в нем), фигурирует в правопорядках практически всех стран с развитой рыночной экономикой» [14, с. 157-172].

Отсутствие этой «странности» наглядно демонстрируют Модельные правила ев- 
ропейского частного права, опирающиеся на опыт европейских стран, неизменно учитывающих при размещении таких понятий в тексте, порядке их толкования общие цели закона, принципы правового регулирования, заложенные в нем, и практические ценности, сопутствующие принятию закона. Но эти отличия между российским и европейским правом во всем, что касается оценочных понятий, не единственные.

\section{«Оценочные» термины \\ в Модельных правилах европейского частного права}

Понятие «европейское частное право» абстрактное и условное. Его цель - демонстрация того, как общее в диспозитивном регулировании имущественных отношений превалирует над различным, а также стремление понять «в какой степени национальные системы частного права схожи между собой и развивались под взаимным влиянием, в какой мере эти правовые системы могут рассматриваться как проявление единого общеевропейского наследия» [10, с. 7].

Конкретное же наполнение понятия «европейское право» раскрывается через доктринальное изложение договорного права наиболее влиятельных стран Западной Европы, что, по сути, означает изложение договорного права и других стран этого региона с соблюдением так называемого метода «гендерной нейтральности». Использование этого метода оказывается неизбежным, учитывая тот факт, что уровень влияния римско-канонического права на правовые системы Западной, Северной и Восточной Европы исторически был неодинаков.

Предметом регулирования Модельных правил, объединенных в 10 книг, являются отношения сторон в сфере заключения, действительности и толкования договоров, определения видов их условий, исполнение возникающих обязательств и средства защиты на случай их неисполнения. Есть также положения о множественности лиц, передаче прав требования, зачете и давности. Авторы объясняют это тем, что довольно сложно провести правильную границу между договорным правом (в широком смысле) и некоторыми ины- ми областями права, отмечая, что обязательственное право рассматривается в DCFR как органичное целое [10]. При этом затронуты так же некоторые вопросы вещных прав на движимое имущество в связи с тем, что отдельные аспекты вещного права имеют большое значение для эффективного функционирования внутреннего рынка.

Самостоятельную группу норм в отдельных книгах составляют нормы о персонифицированных субъектах. Эта тактика присуща европейскому праву под влиянием права Евросоюза. Речь не идет о договорном праве в целом, а лишь об отдельных отношениях, имеющих связь с вопросами защиты прав потребителя. Например, Директива ЕС от 5 апреля 1993 г. о неправомерном использовании оговорок касается оговорок в договорах, заключаемых с потребителями. Указанная Директива обязала страны ЕС ввести в действие нормы, наделяющие судей правом признавать недействительными договоры, которые в нарушение принципа добросовестности ведут к ущемлению прав потребителей, создавая неоправданно большой дисбаланс договорных прав и обязанностей партнеров (ст. 3 Директивы). Поэтому составители документа уделили внимание как индивидуальным, так и коллективным субъектам договорного права, что отражено в положениях императивных норм, направленных на защиту слабой стороны договора.

Научно-терминологический фонд, относящийся к понятиям, именуемым в российском правоведении оценочными, в европейской науке гражданского права иной: описательные понятия, стандарты, синоним хорошего обычая, отсылочные формулы, принципы, общие оговорки и др. Но дело заключается не в разности терминологии, а в том алгоритме, который заложен в их использовании законодателем.

Вне зависимости от того, как эти понятия именуются в науке, их использование в текстах, относящихся к нормативным, обеспечивает решение проблемы оптимальной обобщенности правовой нормы: она должна быть не слишком казуальной и не излишне обобщенной, то есть позволяющей предупредить спор, а если он возник, то решать каждый конкретный случай, не выходя за общие 
рамки правила поведения, описанного в норме. Абстрактность романской нормы - это то, что обеспечивает единство всех правовых систем континентального типа в плане регулирования максимально возможного числа жизненных ситуаций. Эта нормативная традиция была воспринята практически всеми европейскими правовыми системами, за исключением скандинавских, где и сегодня норма продолжает оставаться носительницей казуальных традиций.

Концептуальная база Модельных правил устроена классически для романо-германского права: формально-юридическая юриспруденция граничит с естественно-правовыми идеями, выраженными с помощью различных правовых элементов. Это следует из тех составляющих, которые наполняют содержание Модельных правил: определения как элементы, направленные на развитие единообразной юридической терминологии; принципы, лежащие в основе толкования и применения Модельных правил, а также сами модельные нормы.

Основное содержание Модельных правил образуют книги 1-3, которые считаются общей частью правил, и специальная часть, состоящая из 4-7 книг.

В книге I «Общие положения» с использованием оценочных понятий даны определения добросовестности, честной деловой практики, разумности. Термином «добросовестность и честная деловая практика» поименовано понятие, обозначающее стандарт поведения, характеризующийся честностью, открытостью и уважением интересов другой стороны сделки или соответствующего правоотношения. Противоречащим добросовестности и честной деловой практике является, в частности, поведение, не соответствующее предшествующим заявлениям или поведению одной стороны, при условии, что другая, действуя себе в ущерб, разумно положилась на них [15, с. 107]. Место расположения этих определений, открывающих первую книгу Модельных правил, свидетельствует о том, что речь, по сути, идет о той генеральной оговорке, с учетом которой европейскому частному праву предстоит функционировать.

Разумность должна быть установлена объективно, с учетом природы и цели совер- шаемого действия, обстоятельств дела, а также соответствующих обычаев и сложившейся практики. Формулировка принципа разумности не исключает его соотношения с принципом добросовестности и честной деловой практики как формы (добросовестность) и содержания (разумность). Термин «объективно» указывает на то, что он ближе к добросовестности как требованию к поведению субъекта, то есть добросовестности объективной, имея расчет на среднего субъекта, действующего в обычных обстоятельствах.

Внедрение категории «добросовестность», вполне заслуживающей статуса основы общеевропейского права, находило и находит немало объяснений в доктрине. Более объективным считается подход, основанный на римских традициях, поскольку на земле нет ни одного европейского законодательства, которое в той или иной степени не оказалось бы «процеженным через науку римского права» (высказывание Г.С. Мэйна из книги «Древний закон» цит. по: [23, с. 248]).

Общепризнанным является положение, согласно которому понятие «добрая совесть», «добрые нравы», как одно «из симпатичных и широких начал» (Д. Гюшан), необходимых для управления античным римским миром, восходит к римскому праву. У каждой европейской страны этот путь был собственным в зависимости от времени освоения римского права, качества и количества научных сил, внутренних социально-экономических условий, определявших в своей совокупности различия в новоевропейском гражданском праве, шло приспособление римского права к праву национальному.

Считается, что в наибольшей мере это удалось праву немецкому, впитавшему результаты изучения римского права в его лучшей редакции, представленной Дигестами (Пандектами) Юстиниана. Именно она была положена в основу германских законодательных актов позднесредневекового и послесредневекового периодов. И совсем не случайно с опорой на заключения немецкого ученого Р. Штаммлера, русский и советский правовед Б.И. Новицкий сделал глубокий вывод о том, что «...указание в законе на сообразование решения с правилами доброй совести не дает судье непосредственного материала для ре- 
шения, но указывает метод объективно правильного выхода, дает направление, в котором нужно идти, разбирая казус; направление это сводится к внесению объективного критерия, согласованного с социальным идеалом; объективный критерий должен стать над субъективными желаниями и требованиями сторон и наметить границу, по которой должны быть размежеваны сталкивающиеся требования; противоречивые субъективные интересы и претензии взвешиваются с точки зрения социального идеала и получают объективное разрешение» $[16$, с. 61].

История развития и познания немецкого права, а также его обычных норм показывает, что соответствуя национальному менталитету, каждое новое немецкое поколение вступало в жизнь с неизменной уверенностью в том, что их предки были порядочными, добросовестными и честными. И каждому новому поколению это предстоит перенять, внося во взаимные отношения доверие, честность, содействие.

Потребовалось примерно 100 лет, чтобы немецкий законодатель впитал в себя понимание того, гражданское право не может существовать без добросовестности как системообразующей категории. Сегодня в немецком праве, а вслед за ним и в европейском, эта категория обозначает общее интерпретационное правило, из которого растут многие правовые инструменты частного права. Сeгодня немецкое договорное право признано оплотом добросовестности, претворяющим в жизнь представления о правильном, надлежащем, добропорядочном поведении, получив статус «донора для других европейских стран» [9, с. 5].

Логика последующего развития представлений о добросовестности впоследствии привела к тому, что закон поднял данный принцип на уровень основной идеи и законодательной ценности, реализуемой через отдельные гражданско-правовые нормы. В действующих немецких учебниках сегодня проводится уже практически бесспорная мысль о том, что принцип добросовестности является общим правовым принципом для самых разных областей права - обязательственного, вещного, трудового, семейного, процессуального и публичного [27, с. 127].
Изучение добросовестности как реально действующего механизма не прекращается в германской правовой доктрине и сегодня. При этом важным источником в исследованиях и систематизации знаний служит правоприменительная практика Суда Европейского Союза и Международных коммерческих арбитражных судов, директив Евросоюза.

Важнейшие достижения в вопросе укрепления позиций добросовестности получили свою реализацию в последней реформе обязательственного права Германии, придавшей оговорке о добросовестности характер генерального масштаба контроля содержания договоров (пар. 307 ГГУ) [11, с. 8-13]. Эти изменения не оставили в стороне и французское законодательство, не отличающееся подвижностью к изменениям. Законодатели этой страны, достойно несущие историческую печать уникальности своего гражданского законодательства, долго не прикасались ко второй книге Кодекса об обязательствах. Тем не менее 10 февраля 2016 г. во Франции был принят Ордонанс № 2016-131 «О реформе договорного права, общего режима обязательств и доказательств обязательств», вступивший в силу с 1 октября 2016 года. Эти изменения расширили границы применения правил о добросовестности. Отныне в обновленной редакции ст. 1104 ФГК содержится установление, согласно которому «договоры должны согласовываться, заключаться и исполняться добросовестно. Эта норма императивна» [26]. Императивность нормы фактически свидетельствует о признании ее основой договорного правопорядка.

Не является случайным и факт совпадения во времени реформы российского обязательственного права 2013-2015 гг., воплотившего аналогичное решение о добросовестности как основе правопорядка, в частности, в норме об основных началах гражданского законодательства, закрепившей в результате реформы добросовестность в качестве принципа (п. 3 ст. 1 ГК РФ). Данное решение было подкреплено установлением принципа сотрудничества и содействия контрагентов в обязательстве (п. 3 ст. 307 ГК РФ), что вполне вписывается в регламент добросовестности.

В Модельных правилах понятие «принцип» используется в нескольких значениях. 
Одно состоит в придании принципам значения норм, не обладающих силой закона. Это предопределено учетом актов, содержащих нормы международного права: Принципов Европейского договорного права (PECL) [29, c. 561]; ч. 1 ст. 31 Венской конвенции о праве международных договоров от 23 мая 1969 г., согласно которой договор должен толковаться добросовестно в соответствии с обычным значением, которое следует придавать терминам договора в их контексте, а также в свете объекта и целей договора [21]; Конвенции Организации Объединенных Наций о договорах международной купли-продажи товаров от 11 апреля 1980 г., согласно которой правила толкования договора, предусмотренные данной Конвенцией, должны пониматься посредством общего принципа о необходимости соблюдения добросовестности в международной торговле (ст. 7); Принципов международных коммерческих договоров УНИДРУА (ст. 1.7 (1)) [19].

Второе значение принципов заключается в их самостоятельной применимости для толкования и применения Модельных правил. Такие принципы сформулированы в ст. I.-1:102: «(1) Настоящие правила должны толковаться и применяться как самостоятельный документ в соответствии с целями и лежащими в их основе принципами. (2) Они должны пониматься в свете применимых актов, гарантирующих права и фундаментальные свободы человека, а также применимых актов конституционного права. (3) При их толковании и применении следует обратить внимание на необходимость обеспечить: (а) единообразие в применении; (b) добросовестность и честную деловую практику; (c) правовую определенность (I.-1:102)» [15].

Книга II «Договоры и иные юридические акты» посвящена маркетингу и преддоговорному поведению сторон. Она выполнена формально-юридическим языком и практически свободна от оценочных понятий. Имеющиеся исключения крайне редки: «разумное предположение» (I.-1:108), «обычно предъявляемые требования к качеству и исполнению» (II.-3:101), «разумное лицо» (II.-8:101).

Книга III «Обязанности и соответствующие права» открывается общими положениями, отсылающими к добросовестности и честной деловой практике: (1) При исполнении обязанностей, при осуществлении права на исполнение, при использовании мер защиты от нарушения и возражений против таких мер защиты или при осуществлении права на прекращение обязанности или договорных отношений все лица обязаны действовать в соответствии с требованиями добросовестности и честной деловой практики. (2) Эта обязанность не может быть исключена или ограничена договором или иным юридическим актом. (3) Нарушение этой обязанности непосредственно не является основанием для использования мер защиты от нарушения какойлибо иной обязанности, но может воспрепятствовать нарушителю использовать или полагаться на свое право, меру защиты или возражение, которые были бы доступны такому лицу в отсутствие нарушения (III.-1:103).

В этой норме специально не раскрывается определение добросовестности и честной деловой практики. Каких-либо иных понятий по типу оценочных в данной книге не приводится.

В книге 4 «Отдельные договоры и вытекающие из них права и обязанности» круг обобщающих понятий расширен за счет связи с оценочной категорией «разумность»: разумный срок (IV.A.-4:302, IV.B.-2:101); разумное предположение (IV.A.-4:304; IV.A.-5:203); противоречие требованиям добросовестности и честной деловой практики (IV.B.-1:104); в разумных пределах (IV.B.-2:103); разумно полагаться, разумно рассчитывать (IV.B.-3:103); разумно предполагать (IV.B.-4:103); разумно ожидаемые меры (IV.B.-3:106); разумные запросы (IV.C.-2:103); разумный интервал (IV.B.-5:103); разумный исполнитель, разумные меры предосторожности (V.C.-2:105); разумное изменение, разумное вознаграждение, разумный ответ (IV.C.-2:109); разумный способ и любое разумное время (IV.C.-3:105); разумно определенная часть (услуги) (IV.C.-4:106); разумно рассматривать (IV.C.-7:102); разумно считать необходимым (IV.C.-8:102).

Аналогичные оговорки дублируются применительно к разным договорам, вошедшим в предмет Модельных правил (хранение, подряд на выполнение проектных работ, информационные и консультационные услуги, медицинские услуги, договор поручения, агентский 
договор, франчайзинг и дистрибуция, договор займа, дарение). В числе других открытых понятий: «эффективно», справедливо / не справедливо, достаточное основание, оправданное / неоправданное (промедление), профессионализм и заботливость.

В разы меньше оценочных понятий в правилах о вещных правах (кн. VIII), здесь присутствуют лишь редкие ссылки на разумное предвидение и понятие добросовестности в его субъективном значении: «не знал и как можно разумно предполагать не мог знать» [15].

\section{Выводы}

Обобщающие понятия с открытой аргументацией давно и оправданно отнесены к устойчивым элементам правового регулирования стран Европы. Они основаны на мировоззрении, культуре и ментальности, исторически характерны для европейской цивилизации.

Как признается в зарубежной доктрине, на основе этих понятий создаются упорядоченные правовые массивы, реализуются взаимосвязанные друг с другом, различные по своему характеру и юридической силе нормативно-правовые акты [30, с. 3-26]. Цель этих установлений не только в юридической самоидентификации норм частного права, но и в обеспечении наряду с формально-определенными нормами должных стандартов в сфере договорно-обязательственного права.

Несходство формулировок в российском и европейском праве отнюдь не самое главное в заявленной проблеме. Гораздо более значителен алгоритм их использования в нормативном материале. В Модельных правилах он выглядит иерархичным, основываясь на базовом определении понятий «добросовестность и честная деловая практика», «разумность», находя продолжение в других оценочных оговорках, которые «работают» в обязательственном праве с обязательной опорой на добросовестность. Тем самым гражданско-правовая солидаризация в сфере договорного права на наднациональном уровне явно демонстрирует процесс привнесения стандартов правомерного поведения, которые берут свое начало от генеральной оговорки о добросовестности участников отношений. Это начало иерархии всех остальных оценочных понятий, которые использованы в тексте Модельных правил. Вопреки распространенному мнению о том, что широкое применение принципа добросовестности существенно снижает уровень правовой определенности в гражданском праве, текст Модельных правил свидетельствует, как представляется, об обратном. Основная задача развития в направлении повышения эффективности правового регулирования с учетом изложенного состоит в расширении использования оценочных понятий судами, в том числе с учетом опыта их применения при осуществлении правосудия в европейских странах на основе наднациональных норм.

\section{СПИСОК ЛИТЕРАТУРЫ}

1. Бар, К. Предисловие к российскому изданию / К. Бар, Э. Клив, П. Варул // Модельные правила европейского частного права. - М., 2013. C. 17-47.

2. Беседкина, Н. И. Категория разумности в договорных обязательствах / Н. И. Беседкина // Образование и право. - 2016. - № 3. - С. 85-94.

3. Богданов, Д. Е.Тенденции развития договорного права: поиск новой парадигмы // Реформа обязательственного права России: проблемы и перспективы : монография / под ред. Е. Е. Богдановой. - М. : Проспект, 2018. - 416 с.

4. Варул, П. Принципы и модельные правила европейского частного права / П. Варул // Закон. 2014. - № 6. - С. 56-61.

5. Вилкова, Н. Г. Договорное право в международном обороте / Н. Г. Вилкова. - М. : Статут, 2002. $-511 \mathrm{c}$.

6. Вильнянский, С. И. Применение норм советского права / С. И. Вильнянский // Ученые записки Харьковского юридического института. 1956. - Вып. 7. - С. 3-18.

7. Власова, Г. Б. Влияние европейского частного права на развитие частного права в России / Г. Б. Власова // Россия и ЕС: пути развития и перспективы : материалы Междунар. науч.-практич. конф. - Ростов н/Д, 2016. - С. 557-561.

8. Давыдова, М. Л. Юридическая техника: проблемы теории и методологии : монография / М. Л. Давыдова. - Волгоград : Изд-во ВолГУ, 2009. $-318 \mathrm{c}$.

9. Егоров, В. А. Вступительное слово А.В. Егорова / В. А. Егоров // Возврат исполненного по расторгнугому нарушенному договору: сравнительный анализ российского и немецкого права / Е. А. Папченкова. - М. : Статут, 2017. - С. 4-7. 
10. Елисеев Н.Г. На пути к европейскому частному праву // Вся Европа.ru. - 2011. - № 6 (45). Электрон. текстовые дан. - Режим доступа: http:// alleuropa.ru/?p=2519.

11. Карлявин, И. Ю. К вопросу о контроле содержания договоров Европейского союза, конституционном и частном праве Германии / И. Ю. Карлявин // Научный поиск. - 2015. - № 1.4. - С. 8-13.

12. Концепция развития гражданского законодательства Российской Федерации (одобрена Советом при Президенте РФ по кодификации и совершенствованию гражданского законодательства 7 октября 2009 г.) // Вестник ВАС РФ. - 2009. - № 11 .

13. Лоренц, Д. В. Срок приобретательной давности в модельных правилах европейского частного права / Д. В. Лоренц // Актуальные проблемы российского права. - 2018. - № 1. - С. 166-179.

14. Маковский, А. Л. Об уроках реформирования Гражданского кодекса России / А. Л. Маковский // Вестник гражданского права. - 2013. - № 5. C. $157-172$.

15. Модельные правила Европейского частного права / науч. ред. Н. Ю. Рассказова ; пер. с англ. Н. Ю. Александрова [и др.]. - М. : Статуг, 2013. -989 с.

16. Новицкий, И. Б. Принцип доброй совести в проекте обязательственного / И. Б. Новицкий // Вестник гражданского права. - 1916. - № 6. - С. 60-63.

17. Покровский, И. А. Основные проблемыгражданского права / И. А. Покровский. - М. : Статут, 1998. - 353 с. - (Классика российской цивилистики).

18. Полдников, Д. Ю. Проект общей справочной системы в контексте развития европейского частного права / Д. Ю. Полдников // Законодательство. - 2010. - № 7. - С. 65-74.

19. Принципы международных коммерческих договоров УНИДРУА 2010 / пер. с англ. А. С. Комарова. - М. : Статут, 2013. - LXXIV, 758 c.

20. Пугинский, Б. И. Принципы Европейского договорного права: юридическая природа, основные положения и перспективы развития / Б. И. Пугинский, А. Т. Амиров // Коммерческое право.2011. - № 2 (9). - C. 104-201; 2012. - № 2. - C. 102187 ; 2013. - № 1. - С. 154-225.

21. Сборник международных договоров СССР / МИД СССР. - М. : Междунар. отношения, 1988. Вып. 42: Международные договоры СССР, вступившие в силу с 1 января по 31 декабря 1986 года. 456 с. - (Официальное издание).

22. Сулейменов, М. К. Добросовестность в гражданском праве: проблемы теории и практики / М. К. Сулейменов // Добросовестность в гражданском праве : материалы Междунар. науч.-практ. конф. в рамках ежегод. цивилистич. чтений, посвящен. 20-летию Гражданского кодекса Республики Казахстан (Алматы, 22-23 мая 2014 г.) / отв. ред. М. К. Сулейменов. - Алматы, 2014. - С. 10-25.
23. Стоянов, А. Методы разработки положительного права и общественное значение юристов от глоссаторов до конца XVIII столетия / А. Стоянов. Харьковъ : Тип. Чеховского и Зарина, 1862. -275 с.

24. Фетисов, О. Е. Оценочные понятия в праве: проблемы теории и практики : автореф. дис. ... канд. юрид. наук / Фетисов Олег Евгеньевич. - Тамбов, 2009. -23 c.

25. Фон Бар, К. Общая система координат европейского частного права: академические усилия и политические реалии / К. фон Бар // Журнал зарубежного законодательства и сравнительного правоведения. - 2012. - № 5. - С. 26-33.

26. Journal Officiel. - Electronic text data. http://www.journal-officiel.gouv.fr.

27. Larenz, K. Lehrbuch des Schuldrechts : in 3 buch / K. Larenz. - München : C.H. Beck'sche Verlagsbuchhandlung, 1987.-B. 1: AllgemeinerTeil. $668 \mathrm{~s}$.

28. Regional Private Law and Codificanion Europe / ed. by H. MacQueen, A. Vaquer, S. Espiau. -Cambrige, 2003. - P. 250-259.

29. Principles of European Contract Law. Parts III / ed. by O. Lando, H. Beale. - Hague ; London ; Boston, 2000.

30. Usher, Y. General Principles of EC Law / Y. Usher. -N. Y., 1998. - P. 3-26.

\section{REFERENCES}

1. Bar K., Kliv E., Varul P. P. Preface to the Russian Edition. Model Rules of European Private Law. Moscow, 2013, pp. 17-47. (in Russian).

2. Besedkina N.I. Category of Reasonableness in Contractual Obligations. Obrazovanie $i$ pravo [Education and Law], 2016, no. 3, pp. 85-94. (in Russian). 3. Bogdanov D.E. Reform of the Law of Obligations of Russia: Problems and Prospects. Moscow, Prospekt Publ., 2018. 416 p. (in Russian).

4. Varul P. Principles and Model Rules of European Private Law. The Law, 2014, no. 6, pp. 56-61. (in Russian).

5. Vilkova N.G. Contract Law in International Turnover. Moscow, Statut Publ., 2002. 511 p. (in Russian).

6. Vilnyanskiy S.I. Application of Norms of the Soviet Right. Scientific Notes of the Kharkov Legal Institute, 1956, iss. 7, pp. 3-18. (in Russian).

7. Vlasova G.B. The Influence of European Private Law on the Development of Private Law in Russia. Russia and the EU: Ways of Development and Prospects: Proceedings of the International Scientific and Practical Conference. Rostov-on-Don, 2016, pp. 557-561. (in Russian).

8. Davydova M.L. Legal Technique: Problems of Theory and Methodology. Monograph. Volgograd, Izd-vo VolGU, 2009. 318 p. (in Russian). 
9. Egorov V.A. Introduction. Papchenkova E.A. Return of the Executed Under the Terminated Violated Agreement: Comparative Analysis of Russian and German Law. Moscow, Statut Publ., 2017, pp. 4-7. (in Russian).

10. Eliseev N.G. Towards European private law. All Europe.ru, 2011, no. 6(45).URL: http://alleuropa.ru/ $? \mathrm{p}=2519$. (in Russian).

11. Karlyavin I.Yu. On the Issue of Control of the Content of Treaties of the European Union, Constitutional and Private Law in Germany. Scientific Search, 2015, no. 1.4, pp. 8-13. (in Russian).

12. The Concept of Development of Civil Legislation of the Russian Federation (Approved by the Presidential Council for the Codification and Improvement of Civil Legislation on October 7, 2009). Vestnik VAS RF, 2009, no. 11. (in Russian).

13. Lorents D.V. The Period of Limitation in the Model Rules of European Private Law. Actual Problems of Russian Law, 2018, no. 1, pp. 166-179. (in Russian).

14. Makovskiy A.L. On the Lessons of Reforming the Civil Code of Russia. Bulletin of Civil Law, 2013, no. 5, pp. 157-172. (in Russian).

15. Raskazova N.Yu., ed. Model Rules of European Private Law. Moscow, Statut Publ., 2013. 989 p. (in Russian).

16. Novitskiy I.B. The Principle of Good Conscience in the Draft Law of Obligations. Bulletin of Civil Law, 1916, no. 6, pp. 60-63. (in Russian).

17. Pokrovskiy I.A. The Main Problems of Civil Law. Moscow, Statut Publ., 1998. 353 p. (in Russian).

18. Poldnikov D.Yu. Draft General Reference System in the Context of the Development of European Private Law. The Legislation, 2010, no. 7, pp. 65-74. (in Russian).

19. Principles of International Commercial Contracts UNIDROIT 2010. Moscow, Statut Publ., 2013. LXXIV, 758 p. (in Russian).

20. Puginskiy B.I., Amirov A.T. Principles of European Contract Law: Legal Nature, Main Provisions and Prospects of Development. Commercial Law,
2011, no. 2 (9), pp. 104-201; 2012, no. 2, pp. 102-187; 2013, no. 1, pp. 154-225. (in Russian).

21. The Collection of International Treaties of the USSR. Moscow, Mezhdunarodnye otnosheniya Publ., 1988, iss. 42: Mezhdunarodnye dogovory SSSR, vstupivshie v silu s 1 yanvarya po 31 dekabrya 1986 goda. 456 p. (in Russian).

22. Suleymenov M.K. Integrity in Civil Law: Problems of Theory and Practice. Suleymenov M.K., ed. Good Faith in Civil Law: Materials of the International Scientific-Practical Conference Within the Framework of the Annual Civil Readings Devoted to the 20 $0^{\text {th }}$ Anniversary of the Civil Code of the Republic of Kazakhstan]. Almaty, 2014, pp. 10-25. (in Russian).

23. Stoyanov A. Methods of Development of Positive Law and the Public Importance of Lawyers from Glossators to the end of the XVIII Century. Kharkiv, Tipografiya Chekhovskogo i Zarina,1862. 275 p. (in Russian).

24. Fetisov O.E. Evaluation Concepts in Law: Problems of Theory and Practice. Cand. jurid. sci. abs. diss. Tambov, 2009. 23 p. (in Russian).

25. Fon Bar K. General System of Coordinates of European Private Law: Academic Efforts and Political Realities. Journal of Foreign Law and Comparative Law, 2012, no. 5, pp. 26-33. (in Russian).

26. Journal Officiel. URL: http://www.journalofficiel.gouv.fr.

27. Larenz K. Lehrbuch des Schuldrechts. In 3 Buch. München, C.H. Beck'sche Verlagsbuchhandlung, 1987. Buch 1: Allgemeiner Teil. $668 \mathrm{p}$.

28. MacQueen H., Vaquer A., Espiau S., eds. Regional Private Law and Codificanion Europe. Cambrige, 2003, pp. 250-259.

29. Lando O., Beale H., eds. Principles of European Contract Law. Parts I-II. The Hague; London; Boston, 2000.

30. Usher Y. General Principles of EC Law. New York, 1998, pp. 3-26.

\section{Information about the Author}

Valery G. Golubtsov, Doctor of Sciences (Jurisprudence), Professor, Head of the Department of Business Law, Civil and Arbitration Proceedings, Perm State National Research University, Bukireva St., 15, 614990 Perm, Russian Federation, predprim.pravo@gmail.com, https://orcid.org/0000-0003-3505-2348

\section{Информация об авторе}

Валерий Геннадьевич Голубцов, доктор юридических наук, профессор, заведующий кафедрой предпринимательского права, гражданского и арбитражного процесса, Пермский государственный национальный исследовательский университет, ул. Букирева, 15, 614990 г. Пермь, Российская Федерация, predprim.pravo@gmail.com, https://orcid.org/0000-0003-3505-2348 